\title{
The Impact of FDI on Economic Growth in Case of Romania
}

\author{
Alina Mihaela Ciobanu ${ }^{1}$ \\ ${ }^{1}$ The Romanian Academy, Bucharest, Romania \\ Correspondence: Alina Mihaela Ciobanu, The Romanian Academy, Bucharest, Romania. E-mail: \\ raducanu.alina1984@gmail.com
}

Received: October 6, 2020

Accepted: October 30, 2020

Online Published: November 25, 2020

doi:10.5539/ijef.v12n12p81

URL: https://doi.org/10.5539/ijef.v12n12p81

\begin{abstract}
Foreign direct investment flows had increased worldwide over the last decades and many specialists think that there is a strong correlation among trade, FDI, labor force, and economic growth in the receiving countries. Based on available statistical data, we will examine the effects of FDI on GDP growth and the causality relations between GDP, trade openness, labor force, and FDI in case of Romania for the last decades. The ARDL bound testing approach is used to study the existence of a long-run relationship between FDI, trade, labor, and economic growth. Then the error-correction based Granger causality test is used to test the direction of causality between the variables. The results revealed that there is cointegration among the variables when real GDP and foreign direct investment are the dependent variables. Foreign direct investment, trade openness, and labor force are the main determinants of economic growth in the long run in Romania. In addition, the increase of gross domestic product, exports, imports and labor force promote foreign direct investment in the long run.
\end{abstract}

Keywords: foreign direct investment, economic growth, trade, ARDL model, causality

\section{Introduction}

Economic growth is an economic imperative, the lack of economic growth leading to the increase of the budget deficit, and a social one, by the increase of the society tension, due to the increase of the unemployment and the degradation of the living conditions.

The role of foreign direct investment in the economies of the developed countries continues to be debated and analyzed in the literature, due to the multiple beneficial effects, both direct and indirect, on the host countries, but also due to the increase of the FDI flows following the impact of the globalization and of the intensified links between different financial markets.

In the neoclassical model for economic growth, increases in capital accumulation and labor force contribute significantly to the increase of economic growth (Solow, 1956). The new theory of growth considers technological progress as an endogenous factor and FDI having a major impact on economic growth through technology transfer. Therefore, the FDI flows, by increasing the domestic capital formation, facilitating financing for local firms, will contribute to overall technical progress and productivity spillovers and accelerate economic growth of the host countries (de Mello, 1997; Carkovic \& Levine, 2005).

FDI, as additional foreign capital to the domestic capital stock, is considered to be an essential driver of the developing, emerging and transition countries, because the attraction of FDI can stimulate the capital formation and employment, promote exports, can lead to increased labor productivity through the transfer of managerial know-how, an advanced technology, management and marketing skills favoring the technological process and the sustainable developments, but also a significant financer of the current account deficit and serves as a powerful tool for policy in economic integration.

The main purpose of this paper is to give a comprehensive overview of the impact of FDI on GDP growth and also to investigate the causality relations between GDP, foreign trade, and FDI in case of Romania. While investigating the theoretical and empirical effects of FDI on general economic growth, FDI is considered as an exogenous variable, meaning that any political and economic determinants in the growth analysis, which influence FDI itself, are not taking into consideration.

The results of the econometric model applied show that there is a long-term or equilibrium relationship among real GDP, FDI, trade openness, and labor in Romania. Labor force inflows Granger-cause foreign direct investment meaning that the most efficient way to attract FDI is to focus on the quality of human capital in the 
host country.

Section 2 focuses on a short literature review that supports the existence of a positive relationship between FDI, foreign trade and economic growth. Section 3 gives information about the country specifics of the data and the methodology used to examine the causality relations between GDP growth, exports, and FDI in case of Romania. Section 4 presents the empirical analysis and the last section concludes by summarizing the findings.

\section{Literature Review}

Technological innovations, a fragile regulation of the global financial system, and faster and cheaper communication instruments have allowed investors to diversify their investments overseas. In consequence, a significant increase of capital flows between completely different countries together with direct investment has become an important factor in international economic integration. FDI-based indicators (inward and outward) are among the most widely available and used measures of globalization. By the very nature of its motivation, FDI can promote long-lasting economic and financial links between countries through direct access (Greenfield investments) or indirect access (ownership participations) for investors in home countries to businesses of the host economies.

The impact of FDI on economic growth has been studied until currently in very varied papers and that they have been conducted to the positive link between the high level of GDP and FDI flows, however not for all countries. The direct effects of FDI on economic growth, such as raising productivity and promoting export, and also positive spillovers, such as facilitating transitions toward a market economy and technological diffusion, was the evidence from panel data of China (Zhang, 2006). The larger FDI inflows, the stronger engine of economic growth FDI becomes and is additionally an important vehicle for international capital and technology transfer generally (Neuhaus, 2006).

Most papers had focused on total FDI inflows, in part due to the lack of data. Studding completely different sectors of the economy (manufacturing, primary, and services), FDI could exert different effects on economic growth. In the primary sector, FDI has a negative effect on economic growth, whereas FDI inflows in the manufacturing sector have a positive one and in the service sector, the effect is inconclusive (Alfaro, 2003).

Many empirical studies have shown a positive relationship between foreign direct investment and GDP, but it is very important to know, especially for economic policy decedents, regarding the direction of causality. Corresponding to what is expected from a standard Solow model, Hanse and Rand (2004) found that FDI caused growth via knowledge transfers and new technology, whereas GDP has no long run impact on the FDI. De mello (1999) also finds a positive impact of FDI on output growth via technological upgrading of the capital stocks and knowledge spillovers, through labor training and skills, management practices, however, depends on the degree of complementary and substitution between FDI and domestic capital.

It should be noted that the impact of FDI on the sustainable development of an economy depends to a large extent on the economic conditions of the host country, on the level of existing technological capital, however conjointly on the level of human capital, is a strong complementary effect between FDI and human capital in the process of productivity growth (Borenszterin et al., 1998). Potential foreign investors should be concerned not solely with the total cost of the labor force, however with the labor quality of the host country because a more educated labor force can adopt new technology easily and increase the skill acquisition with a reduced cost. Nevertheless, there may be worries that FDI may lead to a phenomenon of creative destruction (Jude, 2015) on the labor market by the introduction of labor-saving techniques, which lead to a negative impact in employment within the short run, however with positive effect within the long run, as foreign companies create linkages with local companies and their productivity.

However, even if the level of human capital has a positive impact on GDP, this influence is not significant because education contributes with considerable lags (Albulescu, 2015).

The recipient country locations determinants can influence a firm's locational investment choice in order to obtain the highest profitability. De Mello and others (1997) argued that initial conditions of the recipient economy (institutions, trade regime, political risk, policy) play an important role in determining economic performance among transitions economies. Campos and Kinoshita (2003) also find that the institutions and the agglomeration economies are the most important determinant for the geographical patterns of FDI inflows. Using a neoclassical growth theory model in case of post-communism transition economies, Melnyk et al. (2014) showed a significant FDI influence on economic growth but the business climate and positive institutional changes have an important role in the growth rate. The quality of institutions and economic structures are the determinants for attracting FDI inflows in advanced economies (Dellis et al., 2017). 
In case of FDI and home country exports, most studies assert a positive relation between these two variables (Blomstrom et al., 1988, Kravis \& Lipsey, 1988). In an open economy, FDI has reinforcing effects on GDP directly, and indirectly through exports, by the interaction between economic growth and exports (Hsiao, 2006), but also economic growth has effects on trade (Rodrigues \& Rodrik, 2000). Levine and Renelt (1992) suggest an important two-link chain between trade and economic growth through investment and the positive relationship between trade and economic growth may be based on a higher physical investment share and not on the improved resource allocation, which is opposite to the theoretical opinions.

The Heckscher-Ohlin theorem in the trade theory shows that FDI is a substitute, rather than a compliment of commodity trade. However, the "new trade theory" describes FDI and trade as a complementary relationship between asymmetric economies, suggesting that FDI and exports increase simultaneously, and as a substitute between symmetric countries (Markusen \& Venables, 1998).

In case of Romania, the relationship between FDI and economic growth was also analyzed by Misztal (2010), using variables such as GDP, FDI, exports, fixed capital formation, and employment rate, and the study confirmed a strong and positive impact of FDI on economic growth during 2000-2009, but the changes in the employment rate have a very direct impact on economic growth.

The FDI- export- GDP relationship in case of Romania was studied by Albu (2013) and based on empirical data for the last period, he finds that higher values of FDI and exports lead to a rising level of GDP, but this direct correlation is not a linear one, but more complex.

According to Simionescu (2015) and Pelinescu et al. (2009), the direct FDI impact is still insignificant, but the indirect influence, through the increase in productivity and competitiveness is greater and more significant for Romania economy. Using a VAR model, Ludoşean (2012) concluded that the FDI volume does not initiate growth and that economic growth is an important factor in terms of attracting FDI in Romania.

\section{Method}

\subsection{Data}

This research is based on the annual data for Romania during 1991- 2018. The data for the inward FDI stock (mil USD) is provided by UNCTAD, while the data for the rest of the variables are taken from EUROSTAT and World Bank dataset.

In terms of the variables, all data are in current millions USD and converted into natural logarithms. To obtain real values of GDP, GDP was deflated by GDP deflator. Trade openness is measured as the sum of real exports and real imports because imports are as important as exports for the economic growth in developing countries. Although Levine \& Renelt (1992) found that all findings using the share of exports in GDP could be the same using the total trade or import shares.

\subsection{Model}

Taking into account some results presented in the literature, we applied a ARDL model to evaluate the potential impact of FDI, labor force, and trade on economic development in Romania.

Now that we have variables with zero or one order of integration, we can apply the ARDL-bounds testing approach to our econometric model, in order to apply the co-integration methodology proposed by Perasan, Shin, and Smith (2001). In contrast with other multivariate cointegration techniques, such as the Engle and Granger (1987) or Johansen (1995), this bounds testing procedure allows the cointegration test to be estimated by OLS after the order of integrations of the data series is determined and can be applied to studies with small sample size, such as that of the present study.

The following empirical formulation (1) is modeled as a conditional ARDL-error correction model:

$$
\begin{gathered}
\Delta \ln Y_{t}=a+\sum_{i=1}^{p} \alpha_{i} \Delta \ln Y_{t-i}+\sum_{i=0}^{p} \beta_{i} \Delta \ln F D I_{t-i}+\sum_{i=0}^{p} \delta_{i} \Delta \ln L_{t-i}+\sum_{i=0}^{p} \theta_{i} \Delta \ln T R_{t-i}+\mu_{1} \ln Y_{t-1}+ \\
\mu_{2} \ln F D I_{d, t-1}+\mu_{3} \ln F D I_{f, t-1}+\mu_{4} \ln L_{t-i}+\mu_{5} T R_{t-i}+\varepsilon_{0, t}
\end{gathered}
$$

where $\mu_{\mathrm{i}}$ are the long-run multipliers, $\varepsilon_{0, \mathrm{t}}$ are the white noise errors, $\mathrm{p}$ is the optimal lag length and $\mathrm{c}_{0}$ is the drift.

The next step is to estimate equation (2) by OLS to examine the long-run relationship among the variables by conduction an F-test for the joint significance of the coefficients of the lagged levels of the variables $\left(\mathrm{H}_{0}: \mu_{1}=\right.$ $\left.\mu_{2}=\mu_{3}=\mu_{4}=\mu_{5}=0\right)$ against the alternative hypothesis $\left(H_{1}: \mu_{1} \neq \mu_{2} \neq \mu_{3} \neq \mu_{4} \neq \mu_{5} \neq 0\right)$ a long-run relationship exists.

If the F-statistic is above the upper bound critical value, the null hypothesis that the coefficients of the lagged level of the variables are null (i.e. no long-run relationship) will be rejected.

Since the frequency of our observations is annual, the maximum order of the lags must be 2 , as suggested by 
Perasan and Shin (1997).

After the results of the F-statistic, if there is an evidence of a long-term relationship between the examined variables, the model will be the following (2):

$$
\ln Y_{t}=b+\sum_{i=1}^{p} \mu_{1} \Delta \ln Y_{t-i}+\sum_{i=0}^{p} \mu_{2} \ln F D I_{t-i}+\sum_{i=0}^{p} \mu_{3} \ln L_{t-i}+\sum_{i=0}^{p} \mu_{4} \ln T R_{t-i}+\varepsilon_{1, t}
$$

In order to obtain the short-run dynamic parameters by estimating an error correction model (ECM) associated with the long-run estimates, the appropriate model is specified as follows (3):

$\Delta \ln Y_{t}=c+\sum_{i=1}^{p} \alpha_{i} \Delta \ln Y_{t-i}+\sum_{i=0}^{q} \beta_{i} \Delta \ln F D I_{t-i}+\sum_{i=0}^{q} \delta_{i} \Delta \ln L_{t-i}+\sum_{i=0}^{q} \theta_{i} \Delta \ln T R_{t-i}+\psi E C T_{t-i}+\varepsilon_{2, t}$

Where $\mathrm{ECT}_{\mathrm{t}-1}$ refers to the one-period lagged error correction term, specified as follows (4):

$$
E C T_{t-1}=\ln Y_{t}-b-\sum_{i=1}^{p} \mu_{1} \ln Y_{t-i}-\sum_{i=0}^{q_{1}} \mu_{2} \ln F D I_{t-i}-\sum_{i=0}^{q_{2}} \mu_{3} \ln L_{t-i}-\sum_{i=0}^{q_{3}} \mu_{4} \ln T R_{t-i}
$$

The coefficients $\alpha, \beta, \delta$ and $\theta$ are the short-run dynamic coefficients of the model's convergence to long-run equilibrium and $\psi$ is the speed of adjustment.

\section{Results}

\subsection{Stationarity Analysis}

In many cases, the time-series data are non-stationary in level, containing a unit root and the resulted estimates usually provide spurious results (Granger,1981). The first step in the analysis of the country data is to verify the time-series data that are broadly stationary, meaning that the average time series and the series variance have to be stable. From an economic perspective, a series is stationary if the shocks applied to it are absorbed in time and not constantly.

The econometric technique necessitates transforming the values of all real variables into their logarithmic values. Thus, the fluctuations of the four variables are considerably diminished.

We execute unit root stationarity test to check the order of integration of each series and then use the cointegration test, in order to test the causality among the four variables in this study. If these variables (i.e., GDP, FDI, trade openness and labor force) are cointegrated, we must examine the short and the long run Granger causality using error correction models (ECM), instead of a VAR model.

The Dickey-Fuller (DF), the standard Augmented Dickey-Fuller (ADF) and Philips-Perron (PP) test was applied to check the order of integration of these four variables.

According to ADF test, DF test, and PP test, at the $10 \%$ level of significance, the real FDI is stationary. The real GDP, labor force, and the real trade openness are not stationary and therefore, we have proceeded to the differentiation of order 1 of these series and the results show that these series are stationary of 1 order, I(1), meaning that they do not have a unit root, as shown in Table 1.

Table 1. ADF and PP Unit Root Tests

\begin{tabular}{lccccc}
\hline Variables & ADF & PP & Variables & ADF & PP \\
\hline RGDP & -1.204 & -1.253 & D_RGDP & $-5.647 * * *$ & $-5.821^{* * *}$ \\
FDI & $-3.370^{* *}$ & $-6.688^{* * *}$ & D_FDI & $-3.220^{* * *}$ & $-3.2103^{* * *}$ \\
LABOR & -0.636 & -0.663 & D_LABOR & $-4.221^{* * *}$ & $-4.216^{* * *}$ \\
TRADE & -0.843 & -0.866 & D_TRADE & $-4.7163^{* * *}$ & $-4.729^{* * *}$ \\
\hline
\end{tabular}

Note. The symbol $* * * * * * *$ denotes significance at 1,5 or $10 \%$ level.

\subsection{Cointegration Test Based on ARDL Bound Test Approach}

Now if we showed that the series are stationary of 1 order, I(1), we can select the ARDL model and we can examine the long-run relationships among these variables. Maximum lag order in the equations is 2 , as suggested by Perasan and Shin (1997) in case of annual observations.

Different from the traditional methods of estimating cointegrating relationships (Engle-Granger (1987) or Johansen's (1991) method), Pesaran and Shin (1999) showed that cointegrating systems can be estimated using ARDL models, without requiring that all variables to be $\mathrm{I}(1)$ or without needing to pre-specify which are $\mathrm{I}(0)$ or $\mathrm{I}(1)$.

Table 2 presents the results of the F-statistics when each variable is considered as a dependent variable in the ARDL-OLS regressions. 
Table 2. Results from Bounds Tests and F-test Critical values from Perasan, Shin and Smith (2001)

\begin{tabular}{|c|c|c|c|c|c|}
\hline \multicolumn{6}{|c|}{ Bounds Testing approach to cointegration } \\
\hline & & ARDL & & F-statistics & Decision \\
\hline & & $\operatorname{ARDL}(2,0,2,0)$ & & $4.600 * *$ & cointegration \\
\hline & & $\operatorname{ARDL}(1,1,0,2)$ & & $12.641^{* * *}$ & cointegration \\
\hline & & $\operatorname{ARDL}(2,2,0,2)$ & & 4.188 & inconclusive \\
\hline & & $\operatorname{ARDL}(1,1,0,0)$ & & 2.971 & inconclusive \\
\hline \multicolumn{6}{|c|}{ Critical values of the F-statistics: unrestricted constant and no trend } \\
\hline \multicolumn{2}{|c|}{$90 \%$} & \multicolumn{2}{|c|}{$95 \%$} & \multicolumn{2}{|c|}{$99 \%$} \\
\hline $\mathrm{k}$ & $\mathrm{I}(1)$ & $\mathrm{I}(0)$ & $\mathrm{I}(1)$ & $\mathrm{I}(0)$ & $\mathrm{I}(1)$ \\
\hline 3 & 3.77 & 3.23 & 4.35 & 4.29 & 5.61 \\
\hline
\end{tabular}

Note. The symbols *, ** and $* * *$ denote significance at the 10,5 and $1 \%$ levels and $\mathrm{k}$ is the number of regressors.

Sourse: Critical value bounds of F-statistics are from Perasan et al. (2001), table CI(iii), case III: intercept and no trend.

Table 2 presents the results of the F-statistics when each variable is considered as a dependent variable in the ADRL-OLS regressions and the calculated F-statistics $\mathrm{F}_{\mathrm{Y}}(\mathrm{Y} \mid \mathrm{FDI}, \mathrm{L}, \mathrm{TR})$ and $\mathrm{F}_{\mathrm{FDI}}(\mathrm{FDI} \mid \mathrm{Y}, \mathrm{L}, \mathrm{TR})$ are higher than the upper bound critical value 5.61 at the $5 \%$ and $10 \%$ significance level, meaning that there is a long-run relationship among these variables. Thus, the null hypothesis that the coefficients of the lagged level of the variables are null (i.e. no long-run relationship) is rejected, meaning that a long-run cointegration relationship among the variables when the regressions are normalized exist on these variables. For $\mathrm{F}_{\mathrm{L}}(\mathrm{L} / \mathrm{Y}, \mathrm{FDI}, \mathrm{TR})$ and $\mathrm{F}_{\mathrm{TR}}$ (TR/Y, FDI, L) the results of the F-statistics are inconclusive meaning that any causal relationship within dynamic ECM cannot be estimated. The ARDL model is estimated based on the AIC.

With the long-run results obtained, in order to check the stability of the long-run relationship among these variables, we further estimate the long-run effects of FDI, labor, and trade openness on economic growth using the ARDL approach. The selected ARDL $(2,0,2,0)$ model is free from heteroscedasticity, serial correlation and the CUSUM and CUSUM of squares tests reject the presence of structural break (Figures 1,2). The value of R adjusted indicates that $58.4 \%$ variation independent value GDP has been explained by the variations in independent variables, FDI, trade, and labor. The results are presented in Table 3 based on the AIC criteria.

Table 3. Long-run and short-run coefficients of ARDL $(2,0,2,0)$ model

\begin{tabular}{|c|c|c|c|c|c|}
\hline A. Long-run res & & & & & \\
\hline \multicolumn{6}{|c|}{ Dependent variable: $\ln \mathrm{Y}$} \\
\hline Regressor & Coefficient & \multicolumn{3}{|c|}{ Std. error } & t-Statistics \\
\hline $\operatorname{lnFDI}$ & 0.015 & \multicolumn{3}{|c|}{0.136} & 0.112 \\
\hline $\operatorname{lnTR}$ & 2.001 & \multicolumn{3}{|c|}{0.399} & $5.005 * * *$ \\
\hline $\operatorname{lnL}$ & -1.871 & \multicolumn{3}{|c|}{2.729} & -0.685 \\
\hline $\mathrm{b}$ & -10.52 & \multicolumn{2}{|r|}{12.986} & & -0.810 \\
\hline \multicolumn{6}{|c|}{ B. Short-run results } \\
\hline \multicolumn{6}{|c|}{ Dependent variable: $\Delta \ln Y$} \\
\hline Regressor & Coefficient & Std. error & & t-Statistics & Prob \\
\hline$\Delta \ln Y(-1)$ & 0.474 & 0.260 & & 1.821 & 0.087 \\
\hline$\Delta \ln Y(-2)$ & 0.106 & 0.230 & & 0.462 & 0.650 \\
\hline$\Delta \operatorname{lnFDI}$ & 0.116 & 0.416 & & 0.280 & 0.783 \\
\hline$\Delta \ln \mathrm{TR}$ & -0.002 & 0.726 & & -0.003 & 0.997 \\
\hline$\Delta \ln \mathrm{TR}(-1)$ & -1.550 & 0.797 & & -1.943 & 0.069 \\
\hline$\Delta \ln \mathrm{TR}(-2)$ & -1.211 & 0.856 & & -1.413 & 0.176 \\
\hline$\Delta \operatorname{lnL}$ & -4.306 & 4.441 & & -0.969 & 0.346 \\
\hline ECT(-1) & -1.362 & 0.371 & & -3.663 & 0.0021 \\
\hline $\mathrm{b}$ & 0.351 & 0.179 & & 1.957 & 0.068 \\
\hline Diagnostic tests & \multicolumn{3}{|c|}{ Statistics } & \multicolumn{2}{|c|}{ p-value } \\
\hline Adjusted $\mathrm{R}^{2}$ & \multicolumn{3}{|c|}{0.5847} & \multicolumn{2}{|c|}{ 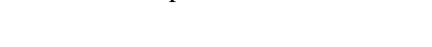 } \\
\hline F-statistics & \multicolumn{3}{|c|}{2.816} & \multicolumn{2}{|c|}{0.0370} \\
\hline Durbin-Watson stat & \multicolumn{3}{|c|}{1.8999} & \multicolumn{2}{|c|}{0.728} \\
\hline $\mathrm{JB}\left(\chi_{\text {NORMAL }}^{2}\right)$ & \multicolumn{3}{|c|}{0.6339} & \multicolumn{2}{|c|}{0.975} \\
\hline $\operatorname{LM}\left(\chi^{2}\right.$ SERIAL $)$ & \multicolumn{3}{|c|}{0.986} & \multicolumn{2}{|c|}{0.771} \\
\hline $\operatorname{RAMSEY}\left(\chi_{\text {RESET }}^{2}\right)$ & \multicolumn{3}{|c|}{0.087} & \multicolumn{2}{|c|}{0.815} \\
\hline $\operatorname{ARCH}\left(\chi_{\mathrm{ARCH}}^{2}\right)$ & \multicolumn{3}{|c|}{0.055} & & \\
\hline
\end{tabular}

Note. The symbols *,** and *** denote 10,5 and $1 \%$ significance level. 
In the long run analysis, the foreign direct investment and the trade openness have a positive impact and highly significant at $1 \%$ level on real GDP in Romania, as we expected, but the labor force has a negative impact on real GDP. The estimate of the coefficient of FDI (0.015) is positive and statistically insignificant at $10 \%$ level of significance. Furthermore, trade openness is positively related to real GDP and this long-run relation is statistically significant at $1 \%$ level of significance. Keeping all else the same, a $10 \%$ increase in trade openness leads to an increase of real GDP by an estimated $2 \%$ in the long term. The labor force, however, does not have a positive impact on the real GDP (-1.871). The results conclude that foreign direct investment and trade openness are the main determinants of economic development in Romania. These findings are consistent with those empirical studies in Hsiao and Hsiao (2006) where it is asserted that FDI and exports are the most determinants of economic development in five Eurozone countries. A greater FDI influence on export growth was also confirmed by older studies of Pelinescu \& Rădulescu (2009) and Albu (2013), in case of Romania.

As the variables are cointegrated, the short-run relationship is estimated using the ECM and the results are given in table 3.B. The coefficient for error correction term represents the speed of adjustment back to the long-run relationship among the GDP, FDI, LABOR, and TRADE while the changes in the variables represent short-run elasticities. So, to have a long-run relationship the sign of the ECT must be negative and statistically significant. In this model, the estimated ECT is -1.362 and is highly significant and implies that $36 \%$ of disequilibria from the previous year's shock adjust back to the long-run equilibrium in the current year.

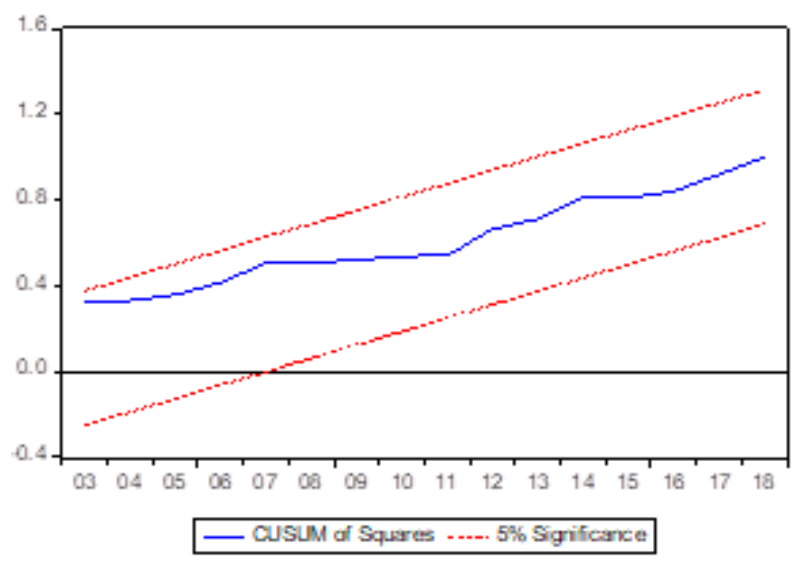

Figure 1. Plot of CUSUM of Squares of Recursive Residuals

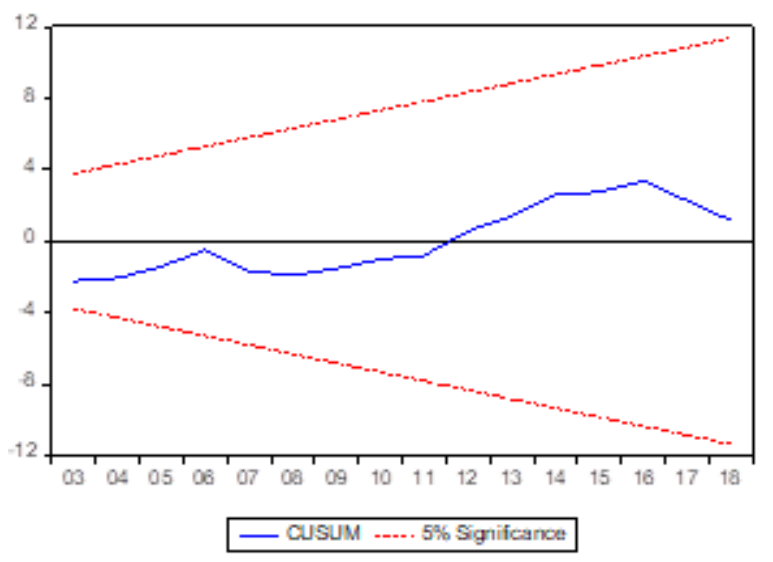

Figure 2. Plot of CUSUM of Recursive Residuals

\subsection{Granger Causality}

Because all the variables are cointegrated, we proceed to analyze the short-run Granger causality in the ECM framework based on Equation (3). The results of the short-run Granger causality test are shown in Table 4. In the short-run, the F-statistics on the explanatory variables suggests that there is a unidirectional Granger causality among FDI and labor force at the $1 \%$ level. This implies that an increase in the quality of human capital leads to an increase in the stock of foreign direct investment, labor force being an important factor in terms of attracting 
FDI in Romania. This conclusion is perhaps expected and is also confirmed by other empirical results of the studies of Borensztein (1998), Emmanuel (2014), and Zaman et al. (2011).

There is no significant Granger causality from FDI to economic growth or from economic growth to FDI in the short-run in Romania. Also, there is no unique short-run Granger causality from trade openness to economic growth or from economic growth to exports and imports.

Table 4. Results of the short- run Granger causality test

\begin{tabular}{cccccc}
\hline Dependent variable & $\Delta \ln \mathrm{Y}$ & $\Delta \operatorname{lnFDI}$ & $\Delta \operatorname{lnTR}$ & $\Delta \operatorname{lnL}$ & ECT(-1) \\
\hline$\Delta \ln \mathrm{N}$ & - & 2.3297 & 0.4983 & 0.5529 & $13.4225^{* * *}$ \\
& & $(0.1294)$ & $(0.7795)$ & $(0.7584)$ & $(0.0021)$ \\
$\Delta \operatorname{lnFDI}$ & 0.0784 & - & 1.0048 & $6.0185^{* * *}$ & 1.0039 \\
& $(0.7830)$ & & $(0.6051)$ & $(0.006)$ & $(0.3313)$ \\
$\Delta \operatorname{lnTR}$ & 1.6285 & 0.7554 & - & 1.9892 & - \\
& $(0.2223)$ & $(0.4609)$ & & $(0.3699)$ & - \\
$\Delta \ln \mathrm{C}$ & 0.3728 & 0.6630 & 2.0033 & - & $(0.3673)$ \\
& $(0.8299)$ & $(0.7178)$ & & & \\
\hline
\end{tabular}

Note. The symbols $*, * *$ and $* * *$ denote 10,5 and $1 \%$ significance level.

\section{Conclusions}

This study provides an analysis of the relationship between foreign direct investment, trade openness, labor force, and economic growth in Romania during the period 1991-2018. The ARDL bounds testing approach is used to study the existence of a long-run relationship between FDI, trade, labor force and economic growth. Then the error-correction based Granger causality test is used to test the direction of causality between the variables. The results revealed that there is cointegration among the variables when real GDP and foreign direct investment are the dependent variables. Foreign direct investment, trade openness, and labor force are the main determinants of economic growth in the long run in Romania. Also, the increase of gross domestic product, exports, imports, and labor force promotes foreign direct investment in the long term.

The most important implication of those econometric results of this research is to use the labor force as the main engine to attract FDI. Romania has a great potential in case of human capital, with technical and digital skills, but the policymakers must implement some reforms in the area of higher-quality education, skills, training, and lifelong learning to support the labor market, facilitating access to the job market, to attract more foreign investors.

\section{References}

Albu, L. L. (2013). Foreign Trade and FDI as main factors of growth in the EU. Romanian Journal of Economic Forecasting, 2, 7-17.

Albulescu, C. T. (2015). Do foreign direct and portfolio investments affect long-term economic growth in Central and Eastern Europe? Procedia Economics and Finance, 23(2015), 507-512. https://doi.org/10.1016/S2212-5671(15)00539-0

Alfaro, L. (2003). Foreign Direct Investment and Growth: Does the Sector Matter? Harvard Business School, April 2003.

Alfaro, L., Chanda, A., Kalemli-Ozcan, S., \& Sayek, S. (2002). FDI and Economic Growth: The Role of Local Financial Markets. https://doi.org/10.2139/ssrn.305762

Blomström, L. Z. (1994). What explains developing country growth? NBER working paper no. 4132.

Bode, E., Nunnenkamp, P., \& Waldkirch, A. (2009). Spatial Effects of Foreign Direct Investment in US States. Kiel Working Paper no. 1535.

Borensztein, E., De Gregorio, J., \& Lee, J. W. (1998). How Does Foreign Direct Investment Affect Economic Growth? Journal of International Economics, 45, 115-135. https://doi.org/10.1016/S0022-1996(97)00033-0

Campos, N. F., \& Kinoshita, Y. (2003). Why does FDI go where it goes? New evidence from the transition economies. IMF Working Paper 03/228. https://doi.org/10.5089/9781451875461.001

Carkovic, M., \& Levine, R. (2002). Does foreign direct investment accelerate economic growth? University of Minnesota. https://doi.org/10.2139/ssrn.314924 
De Mello, L. R. (1999). Foreign Direct Investment-Led Growth: Evidence from Time Series and Panel Data. Oxford Economic Papers, 51, 133-151. https://doi.org/10.1093/oep/51.1.133

Dellis, K., Sondermann, D., \& Vansteenkiste, I. (2017). Determinants of FDI inflows in advanced economies: Does the quality of economic structures matter? ECB Working Paper 2066.

Emmanuel, O. N. B. (2014). Foreign direct investment and economic growth: The evidence of CEMAC countries. Journal of Finance \& Economics, 2, 1-14. https://doi.org/10.12735/jfe.v2i1p1

Geamănu, M. (2014). VAR analysis on foreign direct investment in Romania. Theoretical and Applied Economics, XXI(4), 39-52.

Hansen, H., \& Rand, J. (2006). On the Causal Links between FDI and Growth in Developing Countries. The World Economy, 29. https://doi.org/10.1111/j.1467-9701.2006.00756.x

Jude, C., \& Silaghi, M. I. (2015). Employment effects of foreign direct investment. New Evidence from Central and Eastern European Countries. Bangue de France Working Paper, May 2015. https://doi.org/10.2139/ssrn.2607520

Levine, R., \& Renelt, D. (1992). A sensitivity analysis of cross-country growth regressions. The American Economic Review, 82(4), 942-963.

Ludoşean (Stoiciu), B. M. (2012). A VAR analysis of the connection between FDI and economic growth in Romania. Theoretical and Applied Economics, XIX(10), 115-130.

Melnyk, L., Kubatko, O., \& Pysarenko, S. (2014). The impact of foreign direct investment on economic growth: Case of post communism transition economies. Problems and Perspectives in Management, 12(1), 17-24.

Misztal, P. (2010). Foreign direct investments as a factor for economic growth in Romania. Review of Economic and Business Studies, 1.

Neuhaus, M. (2006). The impact of FDI on economic growth: an analysis for the transition countries of Central and Eastern Europe. Physica-Verlag.

Rodriguez, F., \& Rodrik, D. (2000). Trade policy and economic growth: A skeptic's guide to the cross-national evidence. NBER Macroeconomics Annual 2000, 15, 261-338. https://doi.org/10.1086/654419

Simionescu, M. (2014). The relationship between trade and foreign direct investment in G7 countries a panel data approach. Journal of Economics and Development Studies, 2, 447-454.

Simionescu, M. (2015). Modelling and predicting foreign direct investment in Romania. Review of Economic Studies and Research, $\operatorname{VIII}(1), 125-150$

Solow, R. M. (1956). A contribution to the theory of economic growth. The Quarterly Journal of Economics, 70(1), 65-94. https://doi.org/10.2307/1884513

Won, Y., Hsio, F., \& Yang. (2008). FDI Inflows, Export and Economic Growth in first and second generation ANIEs. Panel Data Causality Analyses. KIEP working paper 08-02.

Zaman, Gh., (2006). Some Macroaspects of FDI in Romania. Romanian Journal of Economics, 22(1(31)), 9-27.

Zaman, Gh., Vasile, V., Matei, M., Croitoru, C., \& Enescu, G. (2011). Aspecte ale impactului ISD din România asupra exporturilor şi dezvoltării durabile. Romanian Journal of Economics.

Zhang, H. K. (2006). Foreign Direct Investment and Economic Growth in China: A Panel Data Study for 1992-2004. Conference of WTO, Beijing.

Zi-Yi, G., \& Yangxiaoteng, L. (2017). Credit Constraint Export in Countries with Different Degrees of Contract Enforcement. Business and Economic Research, 7(1), 227-241. https://doi.org/10.5296/ber.v7i1.10923

\section{Copyrights}

Copyright for this article is retained by the author(s), with first publication rights granted to the journal.

This is an open-access article distributed under the terms and conditions of the Creative Commons Attribution license (http://creativecommons.org/licenses/by/4.0/). 